NICOLAE TURCAN

Crossing: The INPR Journal

Vol. II (2021): 129-133

DOI: $10.21428 / 8766 \mathrm{eb} 43 . \mathrm{fdfad}_{341}$

\title{
A Phenomenological Turn of Eastern Orthodox Theology
}

\author{
Nicolae Turcan \\ Babeș-Bolyai University \\ nicolaeturcan@gmail.com
}

A review of:

Christina M. Gschwandtner, Welcoming Finitude: Toward a Phenomenology of Orthodox Liturgy. New York, NY : Fordham University Press, 2019. pp. 352. \$35.oo.

1. Christina Gschwandtner's book, Welcoming Finitude: Toward a Phenomenology of Orthodox Liturgy (New York: Fordham University Press, 2019), proposes a surprising phenomenology of the Orthodox liturgy. I say "surprising" because there was a lack of communication between phenomenology and theology in the field of Eastern Orthodox theology. Thus, to avoid any theological resistance to a phenomenological method which, to faith, may seem fruitless, Gschwandtner answers preliminary questions such as: Why would liturgical theology need a phenomenological analysis? Could phenomenological philosophy illuminate the liturgical experience of the Orthodox Church? How legitimate is the encounter between phenomenology and theology in the field of ritual?

The answers focus on the concept of "experience," which is common to both phenomenology and Orthodox theology (and liturgy in particular). If Orthodoxy regards experience as a sign of Christian authenticity, then a phenomenological approach is justified: phenomenology itself is a discipline of experience, a description of phenomena which appear to consciousness, overcoming subjective, empirical experience to reveal the structures, meanings, and profound truths of the human being's experience. Phenomenology is a suitable method for theology, although the 


\section{A Phenomenological Turn of Eastern Orthodox Theology}

former has no ambition to replace the latter; it can, however, provide a better understanding of liturgical experience in general and of Christian life in particular. A phenomenology of liturgy is "beneficial to philosophical phenomenology, liturgical theology, and Orthodox thought: by providing a more rigorous grounding for thinking about liturgical experience and by opening new paths for thinking about religious experience more broadly" (29). Phenomenology sheds light on liturgical experience, enriching it not theologically, but culturally and philosophically. Like Jean-Luc Marion, Gschwandtner rigorously distinguishes between phenomenology and theology by admitting the limits of philosophy when discussing religious phenomena.

Can these limits be rigorously preserved, though? Does not the phenomenology of religion mean describing what one cannot see without faith? Christina Gschwandtner admits that the French phenomenologists who deal with theology have a Catholic background, which means that phenomenology is not confessionally neutral. Therefore, by admitting that there is an area between the two, rather than a border, would it not be more legitimate to speak about a form of theophenomenology - a phenomenology colored by the truths of faith?

2. Gschwandtner excellently contends that the temporality of liturgy reveals several tensions: (1) the past and the eschatological future come ec-statically, not magically, into the now-time of the liturgical present; (2) liturgy has a cyclical pattern which alternates between feasting and fasting; (3) there is a becoming of the human person in the experience of liturgical communion, which makes one progress from the discordance of one's life towards concordance and harmony, and the intention of this existential change justifies the length of Orthodox services; (4) liturgy reveals repetitive structures meant to transfigure everyday experience (55-56).

The phenomenology of liturgical spatiality remarks that time and space are bound. The heterogeneity of time corresponds to the heterogeneity of space, which is not equal to itself, but rather differentiated by its role. There is even a cosmic dimension of liturgy; what it is truly essential is the fact that the liturgical space precedes us and determines our behavior (72). The author writes about "intentional space," which "has been prepared by the 'intentionality' directed toward it and organized in concrete ways that allow for an intuitive experience to occur" (73). In opposition to Jean-Yves Lacoste, who considered the liturgical space to be a "nonspace," Gschwandtner states that the liturgical space "has to be entered" (74), because God lives among people not by erasing spatiality, but because architecture and liturgy transfigure everyday spatiality. Another essential idea influenced by Martin Heidegger is that the liturgy "opens a world" through its unique orientation, a world characterized by engagement, communion, and transfiguration. 
As Paul Evdokimov wrote, there are different ages of spiritual life in the Christian tradition, an idea supported by the image of the ladder presented in spiritual literature (Saint John Climacus) and Orthodox iconography. Could liturgical experience have different degrees, which depend on those ages? Are there degrees of the transfiguration of space and time in the liturgy? Could one consider that the saints, being on a higher step of that ladder, sometimes experience the transfiguration of space and time in the liturgy to such an extent that one may still speak of "non-space" and "non-time" (as Lacoste suggests)?

3. The chapter on corporality first distinguishes between body and flesh and, secondly, reviews its different interpretations in French phenomenology: for Michel Henry and Jean-Luc Marion, flesh is affection and emotion; for Maurice MerleauPonty and Emmanuel Falque, it is "more fully "corporeal"; Edmund Husserl and Marion claim that we do not have access to the flesh of the other at all; in contrast, Emmanuel Levinas argues that there is such access in the erotic encounter and in speaking; Henry even speaks of a unity of the flesh (87). Gschwandtner believes that the flesh and the body are in a necessary connection and that liturgy is "fully embodied" (89), heals (93) and "is hard work" (99), having communion in the body of the Church as its goal (100).

Sensoriality is present in the liturgy through the fact that all senses take part in a paradigm that follows the pattern of call and response, engaging the symbolic dimension. Although the senses have intentionality, this does not annihilate the process of transfiguration: "Liturgy takes the ordinary and makes it extraordinary" (106).

Heidegger's affectivity is also present in liturgy, where the participants experience different emotions, but liturgy evokes "a different kind of affectivity" (136), which changes people. The state of apatheia (passionlessness) is not indifference or apathy; on the contrary, it is intentionality, dedication, and attention (135-36). Gschwandtner emphasizes two essential dimensions of liturgical affectivity: consciousness of our finitude and frailty and the need for healing (141).

Do both the phenomenological emphasis on movement, corporeality, senses, and the claim of refusing metaphysics produce a "weak" gaze on the Eucharist? Even though the Eucharist might be an "ordinary" act of eating, it opens a theological and spiritual dimension, which is not a subjective interpretation, but the belief of the Church that Christ's body and blood are real. A phenomenological description can depict gift, corporeality, and affectivity, but from a theological perspective, there is a lot more than that in the Eucharist. Without theology, phenomenology seems ineffectual here: it cannot grasp the essence of the Eucharist, which does not consist in being consummated and venerated, but rather in opening and establishingthrough the act of eating-the Kingdom of God in the souls of the believers. This 


\section{A Phenomenological Turn of Eastern Orthodox Theology}

Kingdom is either an experience of the Holy Spirit here and now or a Kingdom of the future. Does one need more theology to transform the weak gaze on the Eucharist into a richer one? Once again, should phenomenology become theo-phenomenology in order to perceive the phenomenon of the Holy Eucharist adequately?

4. Liturgy belongs to a community more than to a private person, and the community is more than the sum of its participants. Gschwandtner criticizes the phenomenologies of Heidegger, Merleau-Ponty, Henry, Levinas, Marion, and Lacoste, none of whom escapes the primordiality of the ego. Thus, when the ego inaugurates the phenomenological analysis, phenomenology cannot deal with the communion. Community precedes us in liturgy, although it does not become Heidegger's impersonal one. By taking part in the liturgical community, one becomes more authentic: "In identifying with these liturgical 'characters,' we are not erased in our own selfhood, but become more truly ourselves" (164). Liturgy "should not just be observed or contemplated, it has to be practiced and appropriated" (165). It is a space for recognizing our sins and for the moral and religious progress of the human being.

"The one" (das Man) from Heidegger's philosophy cannot describe the importance of the community in liturgy. Could we consider that precedence of the community a "one" belonging to the tradition of the saints, which is not an impersonal one, but rather a sum of their personalities and teachings, by which we become more authentic and progress into our historical and eschatological destiny?

5. The book ends with an analysis of the role of intentionality in liturgy inasmuch as the question of whether or not God could be described phenomenologically remains. Gschwandtner reviews the different opinions of phenomenologists: Levinas, Marion, and Lacoste defended the divine transcendence without eliminating the possibility of experience-trace (Levinas), revelation (Marion), and non-experience (Lacoste). Gschwandtner acknowledges "liturgical intentionality" and "intentional experience," which leads to the conclusion that "the experience given to intuition within liturgy is neither entirely empty (Lacoste) nor exceedingly and overwhelmingly full (Marion)" (184). Liturgical experience means phenomenology and hermeneutics, that is phenomena and words addressed to God. There are apologetic limits because "Phenomenology does not 'prove' God's 'presence' in liturgy—or God's existence in the world" (184).

Given the presence of intentionality in liturgy, should one consider faith as essential intentionality, which is the basis of other forms of intentionality? In Eastern Orthodox theology, there is a strong connection between dogmatics and spirituality, between theology and mystics. Could a phenomenology of liturgy also have a chapter called "Faith"? 
6. The conclusion of the book is similar to its title: liturgy is an invitation to and a welcoming of our finitude, with a view to being healed and transformed. From a phenomenological point of view, the liturgical experience is, first and foremost, a human experience, even though it is an experience of the Divine. "Liturgy matters to our lives as they are lived in their day-to-day existence on this earth in our flesh and bones, engaged with the real people around us, their (and our) affects and emotions in all their concrete, particular, finite, frail, and fully human reality" (203).

Welcoming Finitude: Toward a Phenomenology of Orthodox Liturgy, by Christina M. Gschwandtner, is one of the most consistent answers given from an Orthodox standpoint to the theological turn in French phenomenology. In my opinion, this book starts a phenomenological turn of Orthodox theology, called not to reform or replace theology, but to offer again to our culture, through the language of phenomenology, the Revelation of God brought to human experience and to the intentional gaze of philosophy. 